THE DISTRIBUTIONAL IMPACT OF FISCAL POLICY IN JORDAN Shamma A. Alam, Gabriela Incbauste, and Umar Serajuddin

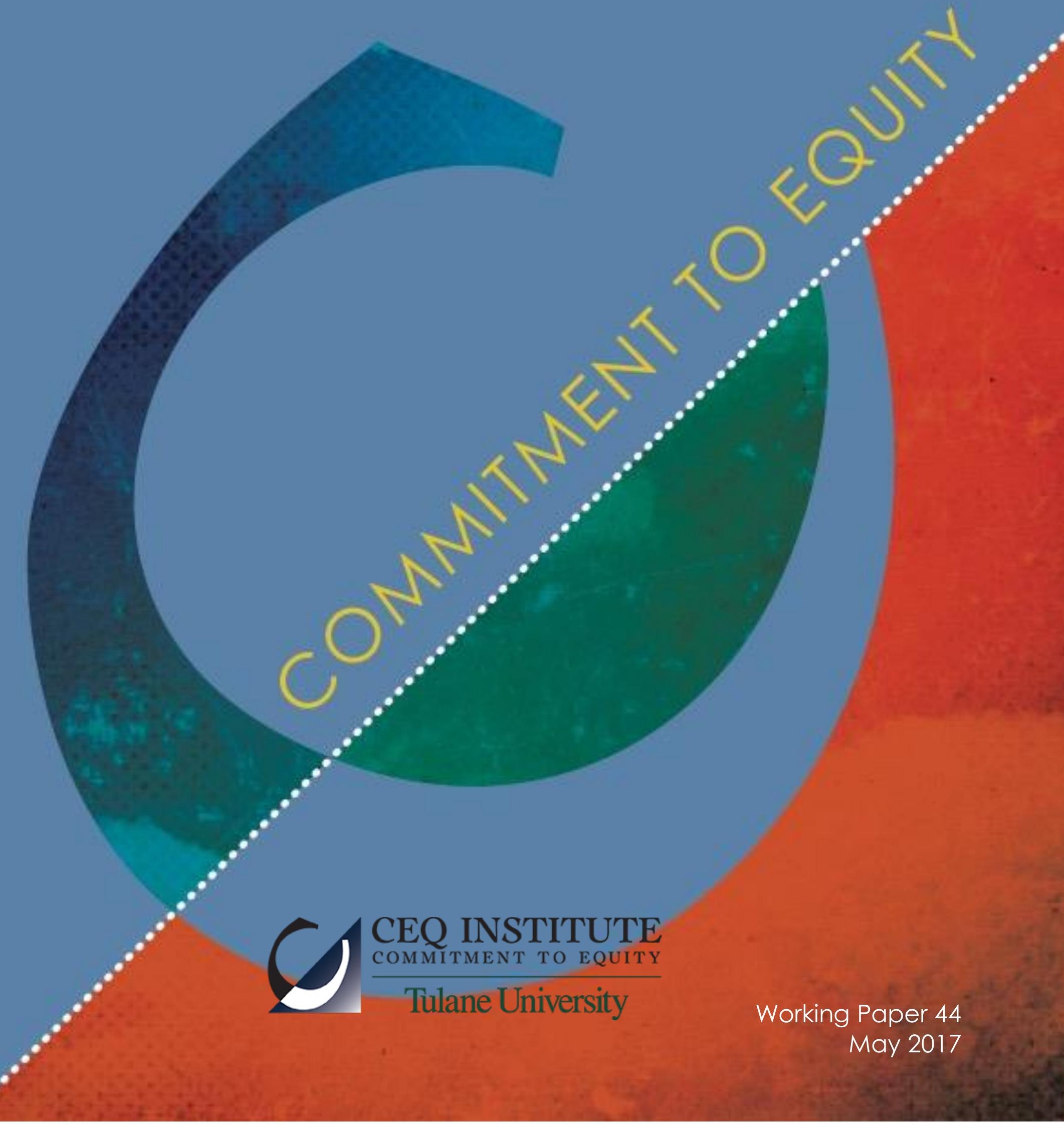




\section{The CEQ Working Paper Series}

The CEQ Institute at Tulane University works to reduce inequality and poverty through rigorous tax and benefit incidence analysis and active engagement with the policy community. The studies published in the CEQ Working Paper series are pre-publication versions of peer-reviewed or scholarly articles, book chapters, and reports produced by the Institute. The papers mainly include empirical studies based on the CEQ methodology and theoretical analysis of the impact of fiscal policy on poverty and inequality. The content of the papers published in this series is entirely the responsibility of the author or authors. Although all the results of empirical studies are reviewed according to the protocol of quality control established by the CEQ Institute, the papers are not subject to a formal arbitration process. The CEQ Working Paper series is possible thanks to the generous support of the Bill \& Melinda Gates Foundation. For more information, visit www.commitmentoequity.org.

The CEQ logo is a stylized graphical representation of a Lorenz curve for a fairly unequal distribution of income (the bottom part of the $\mathrm{C}$, below the diagonal) and a concentration curve for a very progressive transfer (the top part $\mathcal{G}$ TonMitThent of the C). 


\title{
THE DISTRIBUTIONAL IMPACT OF FISCAL POLICY IN JORDAN'
}

\author{
Shamma A. Alam, Gabriela Inchauste, and Umar Serajuddin ${ }^{2}$ \\ CEQ Working Paper 44
}

MAY 2017

\begin{abstract}
This paper analyzes the impact of Jordanian government's fiscal policies on poverty and inequality in the country. The CEQ methodology is applied o analize all the key fiscal policies employed by the government, such as direct taxes (personal income taxes); indirect taxes (sales taxes); direct transfers; indirect subsidies (subsidies for food, oil, electricity, and water); and in-kind benefits (benefits for education and health).

The results indicate that the Jordan's policies are mostly progressive and equalizing, primarily through direct taxes, direct transfers, indirect subsidies, and in-kind benefits. Moreover, the results show that the combination of tax and expenditure policies is poverty-reducing. However, the indirect tax system, in its current form, is slightly regressive and inequality-increasing, as the poor are paying a greater fraction of their income than the rich as sales tax.
\end{abstract}

JEL Codes: H22, I38,D31

Keywords: fiscal policy, fiscal incidence, social spending, inequality, poverty, taxes, Jordan

\footnotetext{
${ }^{1}$ This paper was published as a chapter of The Distributional Impact of Fiscal Policy: Evidence from Developing Countries, edited by Gabriela Inchauste and Nora Lustig, World Bank, 2017. Launched in 2008, the CEQ project is an initiative of the Center for Inter-American Policy and Research (CIPR) and the department of Economics, Tulane University, the Center for Global Development and the Inter-American Dialogue. The CEQ project is housed in the Commitment to Equity Institute at Tulane. For more details visit www.commitmentoequity.org.

${ }^{2}$ Shamma A. Alam is an Assistant Professor at the Department of International Studies, Dickinson College; Gabriela Inchauste is Lead Economist, Poverty and Equity Global Practice, at the World Bank; Umar Serajuddin is a Senior Economist in the World Bank's Development Data Group, where he leads the Sustainable Development Statistics team.
} 


\section{Introduction}

Jordan's economy grew at an average of 6.7 percent a year between 2000 and 2008. This performance was better than the average of the Middle East and North Africa region as a whole, which grew at a rate of about 4.5 percent a year (World Bank 2012b). Jordan's economic growth declined sharply between 2008 and 2009, coinciding with the global financial crisis: real gross domestic product (GDP) growth fell from almost 7.2 percent in 2008 to 2.3 percent in 2010 (IMF 2012).

With strong economic growth in the earlier part of the decade, the country made important social gains. For example, Jordan's growth was accompanied by a large reduction in poverty (DOS and World Bank 2009; Mansour 2012). Even with the decline in per capita output growth in 2009 and 2010, the poverty rate had fallen by an estimated 5 percentage points between 2008 and 2010 (World Bank 2012a), and unemployment remained stable during this period (Inchauste, Mansur, and Serajuddin 2017).

Despite the progress in poverty reduction, the downturn in Jordan's economy starting at the end of 2008 placed its fiscal accounts under pressure as both tax revenues and external grants fell (Inchauste, Mansur, and Serajuddin 2017). This necessitated efforts to streamline government spending and institute reforms. At the same time, popular perceptions regarding Jordan's progress in poverty reduction over this period remained typically pessimistic (DOS and World Bank 2009; Mansour 2012), making reform efforts challenging. Moreover, the regional wave of civil uprisings in 2011 that became known as the Arab Spring placed even stronger demands on the government for populist policies.

In the presence of such economic and social uncertainty, there is significant interest in examining not only the costs and benefits of different policy options but also their equityenhancing attributes. This working paper focuses on the latter, examining the distributional impact of Jordan's key fiscal policies on both the tax and the social spending sides. We use data from Jordan's 2010 Household Expenditure and Income Survey (HEIS) in conjunction with data from administrative accounts, applying the Commitment to Equity (CEQ) methodology in our analysis (Lustig and Higgins 2013). ${ }^{3}$ We cover the impacts of the primary fiscal policies employed by the government, such as direct taxes (personal income taxes); indirect taxes (sales taxes); direct transfers; indirect subsidies (subsidies for food, oil, electricity, and water); and in-kind benefits (benefits for education and health).

Although the data for the study may appear a bit dated, they correspond to the country's most recent official poverty estimates. Major changes have taken place since 2010 — the influx of Syrian refugees perhaps being the most notable - and Jordan currently grapples with how to provide services to its citizens as well as to the refugees. The country has also initiated several

\footnotetext{
${ }^{3}$ For a thorough description of the CEQ project and its methodologies, see Inchauste and Lustig (2017).
} 
ambitious reform efforts, such as drastically reducing subsidies on petroleum products in November 2012 (Atamanov, Jellema, and Serajuddin 2015; Inchauste, Mansur, and Serajuddin 2017).

At the same time, the government's commitment to equity has remained strong. In May 2015 the government launched an economic blueprint- "Jordan 2025: A National Vision and Strategy" - that proposes a 10-year strategy for economic and social development (Government of Jordan 2015). Important targets of this blueprint include halving poverty rates and enhancing equality of opportunity for citizens. In the context of such targets, the study presented in this working paper can serve as a benchmark for assessing the equity or distributional aspects of existing policies and for subsequently assessing the equity aspects of alternative policies.

Our analysis results in several main findings. Among them, we find that the Jordan's fiscal system is mostly progressive, as it decreases the poverty headcount and inequality in the country. More specifically, direct taxes (personal income taxes), direct cash transfer programs, and in-kind education benefits are very progressive. In contrast, indirect taxes appear to be regressive in Jordan, as they seemingly increase income inequality. This suggests that the poor and the middle class could potentially benefit from changes in the general sales tax (GST) system, because they currently spend a greater fraction of their incomes on indirect taxes than do the wealthier households.

We organize this working paper as follows: The next section discusses the fiscal instruments the Jordanian government uses to tackle poverty and inequality, including the income tax, the GST, the direct transfer program, the subsidy program, the pension system, and in-kind benefits such as education and health care. The "Data, Methodology, and Assumptions" section explains the data set and methodology used for our analysis and clarifies the underlying assumptions behind the analysis. The "Results" section presents our findings, focusing on topics such as (a) how inequality changes across different concepts of household income, (b) the details of poverty and inequality measures, (c) the progressivity of Jordan's fiscal system, and (d) the income mobility of poor households. Finally, the "Conclusion" summarizes the working paper's findings.

\section{Fiscal Instruments to Tackle Poverty and Inequality}

\section{Taxes}

Tax revenues account for a significant fraction of Jordan's GDP_for about 15.9 percent of GDP in 2010 - their two largest components being direct taxes (including the payroll tax) and the GST (table 6.1). Our analysis focuses on these two tax items, which directly affected people and accounted for around 34 percent of the government's tax revenue. In addition to 
these two items, the government also collects corporate taxes from private firms and indirect taxes on the commercial sector.

It is important to note that in addition to the GST, the government collects customs duty on imported goods. We cannot include this in our analysis because the household survey data do not identify whether certain expenditures were made for imported goods or services.

Table 1 Government Revenue in Jordan, by Source, 2010

\section{Revenue source}

Total government revenue

Tax revenues

Taxes on income and profits

Personal income tax

Corporate taxes from private firms

GST and other indirect taxes

Sales tax on imported goods

Sales tax on domestic goods

Sales tax on services

Sales tax on commercial sector

Tax on air fares

Other taxes ${ }^{\mathrm{c}}$

Pension contributions

Foreign grants

Other revenues ${ }^{\mathrm{d}}$

\begin{tabular}{ccc}
$\begin{array}{c}\text { Total } \\
\text { (JD, millions) }\end{array}$ & $\begin{array}{c}\text { Share of GDP } \\
\mathbf{( \% )}\end{array}$ & $\begin{array}{c}\text { Share of total } \\
\text { included in } \\
\text { analysis (\%) }\end{array}$ \\
\hline $4,642.1$ & 24.7 & 24.0 \\
$2,986.0$ & 15.9 & 34.7 \\
624.6 & 3.3 & 24.0 \\
152.3 & 0.8 & 100 \\
472.3 & 2.5 & 0 \\
$1,997.8$ & 10.6 & 43.0 \\
819.4 & 4.4 & 0 \\
463.3 & 2.5 & 100 \\
400.4 & 2.1 & 100 \\
304.2 & 1.6 & 0 \\
10.5 & 0.1 & 0 \\
363.6 & 1.9 & 5.7 \\
20.7 & 0.1 & 100 \\
401.7 & 2.1 & 0 \\
$1,254.4$ & 6.7 & 0 \\
\hline & & \\
\hline & & 0
\end{tabular}

Source: $\mathrm{MoF} 2013$.

Note: JD = Jordanian dinars. GST $=$ general sales tax. The table does not include customs duties on imports because household survey data do not identify whether expenditures were for imported goods or services.

a. Total government revenue $=$ tax revenues + other revenues + foreign grants.

b. Tax revenues $=$ taxes on income and profits + GST and other indirect taxes + other taxes.

c. "Other taxes" includes custom duties and fees.

d. "Other revenues" includes revenue from selling goods and services, income from property ownership, mining revenues, and other miscellaneous revenues. 


\section{Direct Taxes}

The Jordanian government collects two forms of direct taxes: personal income taxes for individuals and corporate taxes from the private sector. Since only the income tax directly affects individuals, we examine the effect of income taxes on poverty and inequality in Jordan.

Jordan's income tax system is designed to be progressive: the first JD 12,000 of an individual's income is not taxed; individual income between JD 12,000 and JD 24,000 is taxed at 7 percent, and individual income above JD 24,000 is taxed at 14 percent. The burden of the tax is fully borne by the worker, not the employer. The tax system does not provide deductions for married persons or children.

\section{Indirect Taxes}

Jordan's GST system plays a role similar to that of a value added tax (VAT). Although certain items are zero-rated, certain other items are exempted from taxes altogether. Overall, three different rates of GST are applied across goods and services: 0 percent, 4 percent, and 16 percent. ${ }^{4}$

\section{Social Spending}

The government of Jordan spends a significant amount on different social programsequivalent to about 30 percent of the country's GDP in 2010 (table 2). The following subsections provide more detail on each of these programs.

Table 2 Government Spending in Jordan, by Category, 2010

\begin{tabular}{cccc} 
Category & $\begin{array}{c}\text { Total } \\
\text { (JD, millions) }\end{array}$ & $\begin{array}{c}\text { Share of GDP } \\
\mathbf{( \% )}\end{array}$ & $\begin{array}{c}\text { Share of total } \\
\text { included in analysis } \\
\mathbf{( \% )}\end{array}$ \\
\cline { 2 - 4 } Total government spending $^{\mathrm{a}}$ & $5,708.0$ & 30.4 & 43.0 \\
Primary government spending $^{\mathrm{b}}$ & $5,310.5$ & 28.3 & 46.3 \\
Social spending & $1,708.6$ & 9.1 & 89.2 \\
Total cash transfers & 136.0 & 0.7 & 100 \\
Direct cash transfers (NAF) & 77.4 & 0.4 & 100 \\
Other transfers & 58.6 & 0.3 & 100
\end{tabular}

\footnotetext{
${ }^{4}$ For a detailed list of tax-exempt items and items with different tax rates, see the U.S. Agency for International Development report, "Evaluating Tax Expenditures in Jordan" (Heredia-Ortiz 2013).
} 


\begin{tabular}{crcc} 
Total in-kind transfers $^{\mathrm{d}}$ & $1,388.2$ & 7.4 & 100 \\
Education & 597.3 & 3.2 & 100 \\
Health & 581.2 & 3.1 & 100 \\
Contributory & 215.0 & 1.1 & 100 \\
Noncontributory & 366.2 & 2.0 & 100 \\
Housing and urban & 209.8 & 1.1 & 100 \\
Other social spending & 184.4 & 1.0 & 0 \\
Non-social spendinge & $2,856.9$ & 15.2 & 100 \\
Indirect subsidies & 191.2 & 1.0 & 100 \\
On final goods & 123.8 & 0.7 & 100 \\
On inputs/oil & 67.4 & 0.4 & 100 \\
Other non-social spending & $2,666.0$ & 14.2 & 0 \\
Contributory pensions & 745.0 & 4.0 & 100 \\
Interest payments & 397.5 & 2.2 & 0 \\
\hline
\end{tabular}

Source: MoF 2013.

Note: $\mathrm{JD}=$ Jordanian dinars. NAF $=$ National Aid Fund.

a. Total government spending $=$ primary government spending + interest payments on debt.

b. Primary government spending $=$ social spending + non-social spending + contributory pensions.

c. Social spending $=$ total cash transfers + total in-kind transfers + other social spending.

d. Total in-kind transfers $=$ education + health + housing and urban.

e. Non-social spending $=$ indirect subsidies + other non-social spending.

\section{Direct Transfers}

Jordan has an unconditional cash transfer program, the National Aid Fund (NAF), which accounted for about 0.4 percent of GDP in 2010. NAF's target population includes families taking care of orphaned children, elderly individuals, persons with disability, families headed by divorced or abandoned women, women with young children, families whose breadwinner is in prison, humanitarian cases, abandoned women, persons receiving assistance and rehabilitation loans, families of seasonal workers, families of missing and absentee fathers, and persons with no income (Silva, Levin, and Morgandi 2013).

To receive NAF benefits, a household's income must be below a preset per capita threshold. All NAF beneficiaries also are automatically eligible for health insurance. The fund provides the beneficiaries with monthly cash transfers ranging from JD 40 to JD 180 depending on 
income, assets, and family circumstances. Approximately 88,000 families benefit from this program each year (Silva, Levin, and Morgandi 2013). ${ }^{5}$

Another small cash transfer program is the Zakat Fund, which provides direct monetary assistance to orphans and children in targeted families. ${ }^{6}$ It is an obligatory charity paid once a year (the first day of the month of Ramadan) by wealthy Muslims based on a percentage of savings and certain types of assets. Its scope is far smaller than the NAF's, providing cash assistance only to extremely poor individuals.

Besides these cash transfer programs, the government provides other transfers to certain poor and vulnerable populations through four programs: Handicapped Affairs, Social Defence, Community Development and Combating Poverty, and Family and Childhood Protection. ${ }^{7}$ These programs help households with wide-ranging issues and include assistance to combat poverty; assistance to ensure the well-being of people with disabilities through rehabilitation services, education, and institutional care; assistance to families in the upbringing of children; assistance to protection of families from disintegration; awareness programs for needy families; and assistance to improve the housing conditions of the poor. In addition to these transfers, the King's funds provide further assistance to the needy.

\section{In-Kind Transfers}

Public education. Jordan's government spent an amount equivalent to 3.2 percent of the country's GDP on education in 2010. The country's education system consists of kindergarten, basic schooling, and secondary schooling. Basic schooling (primary and middle school) and secondary schooling are free; at the same time, education is compulsory for all children until the age of 15 (Al Jabery and Zumberg 2008; DOS 2012). An estimated 71 percent of all students go to public schools for basic schooling, and 86 percent go to public schools for secondary schooling (DOS 2012).

After completing basic schooling, the students continue on one of two secondary-school tracks: either an academic track or a vocational track (Al Jabery and Zumberg 2008). In the academic track, students complete secondary school with a general secondary school examination. The vocational track consists of specialized courses and aims to prepare students for employment as skilled labor.

\footnotetext{
${ }^{5}$ For more information about the NAF, see "Jordan: Schemes-National Aid Fund" on the International Labour Organization website, accessed February 1, 2016, http://www.ilo.org/dyn/ilossi/ssimain.viewScheme?p lang=en\&p geoaid=400\&p scheme id=1665.

${ }^{6}$ For more information about the Zakat Fund, see "Jordan: Schemes-National Zakat Fund" on the International Labour Organization website, accessed May 21, 2016, http://www.ilo.org/dyn/ilossi/ssimain.viewScheme?p lang=en\&p scheme id=3233\&p geoaid=400.

${ }^{7}$ For more information about these social assistance programs, see "Jordan: Schemes-Ministry of Social Development" on the International Labour Organization website, accessed February 1, 2016, http://www.ilo.org/dyn/ilossi/ssimain.viewScheme?p lang=en\&p scheme id=3234\&p geoaid=400.
} 
Health benefits. Jordan has one of the most modern health care infrastructures in the Middle East (WHO 2006). In 2010 the government spent an amount equivalent to 3.1 percent of the country's GDP on health benefits. These expenditures include the costs of highly subsidized health care at public primary health care centers and hospitals as well as investments in research and development (MoH 2012; WHO 2006).

Jordan's public health insurance program covers about 40 percent of the population, mostly civil servants and the very poor (MoH 2012; WHO 2006). The insurance coverage is expected to expand substantially in the coming years.

\section{Indirect Subsidies}

As it does for health and education benefits, Jordan also provides significant indirect subsidies on food, petroleum products, electricity, and water. ${ }^{8}$

Food subsidies. The government sells imported wheat and barley to consumers at a subsidized price. A World Bank study shows that completely removing wheat subsidies would increase its price by 68 percent and adversely affect the poorer population if unaccompanied by any offsetting measures (World Bank 2012b). The government also subsidizes flour and bread so that people can buy such items at a low price. Although barley is not directly consumed by households, it is consumed by animals such as livestock, and subsidized barley puts a downward pressure on the price of meat in Jordan (World Bank 2012b).

Fuel subsidies. In 2011, government subsidies on petroleum products-liquefied petroleum gas (LPG), kerosene, gasoline, and diesel_amounted collectively to about 2.8 percent of GDP. The government provided these subsidies to energy companies to cover the difference between the cost of production and the selling price (World Bank 2012b).

Electricity subsidies. Electricity subsidies in 2010 amounted to around 1 percent of GDP, but in 2011 they rose to about 5.5 percent of GDP because political unrest disrupted the supply of natural gas from the Arab Republic of Egypt, causing Jordan to abruptly switch to imported oil products (heavy fuel oil and diesel) to produce electricity (Atamanov, Jellema, and Serajuddin 2015).

Water subsidies. Jordan subsidizes water consumption and provides water subsidies through discounts on water bills depending on the amount of consumption. A World Bank study estimated that removal of this subsidy would cause the water price to increase by 257 percent (World Bank 2012b).

\footnotetext{
8 Although government accounts indicate that government spending on subsidies in Jordan is equivalent to 1 percent of GDP, indirect subsidies in fact amounted to about 3 percent of GDP in 2010. The disparity occurs because calculations in the government accounts exclude electricity and water expenditures. For example, electricity losses incurred by NEPCO (National Electricity Production Company) have been financed not from the government's budget but from debt raised and guaranteed by the government on behalf of NEPCO (World Bank 2012b). For consistency, table 6.2 includes only the numbers from the government accounts.
} 


\section{Pensions}

Jordan has a public contributory pension (pay as you go) system, with three types of pensions in place. The Social Security Corporation manages the national pension system for private sector workers, for public employees who joined the civil services after 1995, and for army personnel recruited after 2002. ${ }^{9}$ The current mandatory contribution rate is set at 14.5 percent of the worker's salary, of which 5.5 percent is paid by employees and the rest by the employer. It is now a mandatory scheme for all employers. Self-employed workers have to pay the entire 14.5 percent of their income on their own. However, government employees recruited before 1995 are covered by the Civil Pension System, and members of the military recruited through 2002 are covered under the Military Pension System. ${ }^{10}$

\section{Data, Methodology, and Assumptions}

\section{Data}

As mentioned earlier, our study uses data from the Household Expenditure and Income Survey (HEIS), conducted by Jordan's Department of Statistics. This survey interviewed around 11,000 households over the course of 12 months from April 2010 to March 2011. It contains detailed data on household expenditure and income as well as data on potential sources of income, direct transfers, and household use of education and health services. Additionally, we use 2010 administrative and national accounts data that broadly coincide with the time frame of the household survey.

\section{Methodology and Assumptions}

\section{Income Concepts}

Our incidence analysis is conducted in the context of the five CEQ income concepts, as described in Lustig and Higgins (2013): market income, net market income, disposable income, consumable income, and final income. Because income is typically presumed to be underreported in household survey data (Atkinson and Brandolini 2001; Deaton 1997; Ravallion 2003; Thomas, Strauss, and Henriques 1991), we start our computation by equating household total expenditure with "disposable income." From that, we subtract direct transfers

\footnotetext{
${ }^{9}$ For more information about the national pension system managed by the Social Security Corporation, see "Jordan: Schemes-Social Security Corporation ISSC [Old Age, Disability and Death Insurance and Work Injury]" on the International Labour Organization website, accessed May 24, 2016, http://www.ilo.org/dyn/ilossi/ssimain.viewScheme?p lang=en\&p scheme id=532\&p geoaid=400.

${ }^{10}$ For more information about the Civil Pension System and Military Pension System, see "Jordan: SchemesGovernment Pension Fund (Civil Servants and Military)" on the International Labour Organization website, accessed May 24, 2016, http://www.ilo.org/dyn/ilossi/ssimain.viewScheme?p lang=en\&p scheme id=2632\&p geoaid=400.
} 
to generate "net market income." To this we add the amounts paid in direct taxes to generate "market income." We also compute household "consumable income" by adding indirect subsidies and subtracting indirect taxes from disposable income. Last, we produce household "final income" by adding in-kind health and education benefits and subtracting user fees for using such services from consumable income. ${ }^{11}$

Next we explain how we assigned monetary values to the government's different fiscal interventions, broadly categorized as taxes (income and sales taxes) and transfers (direct transfers, pensions, indirect subsidies, and in-kind transfers).

\section{Taxes}

Because HEIS does not report household taxes, we simulate the income tax paid by households by assuming that households follow the income tax code. Although tax evasion could be potentially large, we cannot model these evasions for lack of data. Following the tax code, for individual incomes below JD 12,000 (which are tax-exempt), we assume that individuals paid no income tax. For individual income between JD 12,000 and JD 24,000, we apply a marginal tax rate of 7 percent; for additional income above JD 24,000, we apply a marginal tax rate of 14 percent.

In the absence of GST data, we simulate the sales taxes paid by the households using the government's statutory rates. Because the HEIS data do show itemized household expenditures, we can impose the sales tax rates for the different items, which allows us to simulate the total sales tax paid by the households on all items. Sales taxes are probably not paid on expenditures in informal markets, but because we cannot identify such expenditures, it is not possible to calculate the evasion of such sales tax payments.

\section{Transfers}

The HEIS data include household income generated from direct transfer programs. The survey asked households about their previous year's earnings from the NAF program as well as the amount of transfers they had received from other government institutions.

We can also identify directly from the HEIS data whether an individual is receiving a pension and, if so, the amount. Throughout this working paper we treat pensions only as deferred income.

Moreover, the HEIS data include the amounts of household expenditures on the various items receiving indirect subsidies (including food, fuel, electricity, and water). From these itemspecific expenditures we impute the direct and indirect benefits households receive from indirect subsidies.

\footnotetext{
${ }^{11}$ Inchauste and Lustig (2017) provides a detailed explanation of how the CEQ income concepts are constructed.
} 
Because the HEIS data do not include the in-kind transfers received in the form of education or health benefits, we simulate these benefits as described below.

Education. The household survey data include whether an individual goes to a public school or university, and if so, the level of education that the individual is receiving (kindergarten, primary, secondary, vocational, or university). Additionally, from national accounts, we have data on government expenditure on education allocated by different levels of education.

The national accounts also provide data on the total number of students at the different education levels, enabling us to estimate the education benefits received by each student. Then we impute these education benefits per student to the corresponding students in the household survey. In addition to the benefits arising from these government expenditures, there are infrastructure costs that are not allocated by education level in the national accounts. We apportion those costs equally among all the students receiving education in public schools.

Finally, because our total income in the household data is significantly less than the total income in administrative data, we have scaled down the education benefits imputed to the households. ${ }^{12}$ We do so by multiplying the imputed education benefits by the ratio of surveydata income to administrative-data income.

Health. The HEIS data include information on households' health expenditures, including expenditures related to visits to public hospitals. Most households visiting public hospitals had to pay at least a small user fee. Such fees vary greatly, possibly indicating the variation in the severity of illness and the benefit the individual is receiving. We assume that an individual who is paying a higher fee is likely to receive greater health benefits (because higher fees may indicate a greater severity of illness and greater use of health facilities) than an individual paying lower fees. Therefore, we impute larger health benefits for households that paid higher user fees, with the imputed health benefits increasing proportionally with the amount of user fees paid. Then we subtract the user fees from the health benefits received by the individual.

Although our assumptions regarding the imputation of health benefits are strong, it is important to note that we lack both government expenditure data and survey data on the types of health services received (for example, medical checkups, hospitalization, and so on). That is why we allocate the benefits according to the health expenditure made by individual households. As with the education benefits, we have scaled down the health benefits imputed to the households by the ratio of income reported in survey data and income in administrative data.

\footnotetext{
${ }^{12}$ For a discussion of the rationale and methodology for scaling up or scaling down certain transfers in the calculation of the income aggregates, see Inchauste and Lustig (2017).
} 


\section{Results}

\section{Changes in Inequality across Income Concepts}

We start our analysis by exploring how fiscal interventions affected the share of cumulative income in Jordan earned by the poorest, the middle, and the richest income groups. To conduct this analysis, we first rank households by income decile. Then we examine the percentage of cumulative income in Jordan earned by each decile under the following three income concepts: market income, consumable income, and final income. If households in the lower deciles earn a greater percentage of the cumulative income in their final income relative to their market income, it would suggest that the fiscal interventions are helping to reduce inequality in the country.

We present the results in Figure 1. The results suggest that the poorest three deciles are slightly wealthier according to their final income than according to their market income. In contrast, the richest decile is slightly less wealthy in final income relative to market income. Interestingly, we find no significant difference between market income, consumable income, and final income for the middle deciles. Overall, the graph suggests that Jordan has a slightly progressive fiscal policy in place. 


\section{Figure 1 Share of Total Household Income in Jordan, by Decile and Income Concept,}

2010

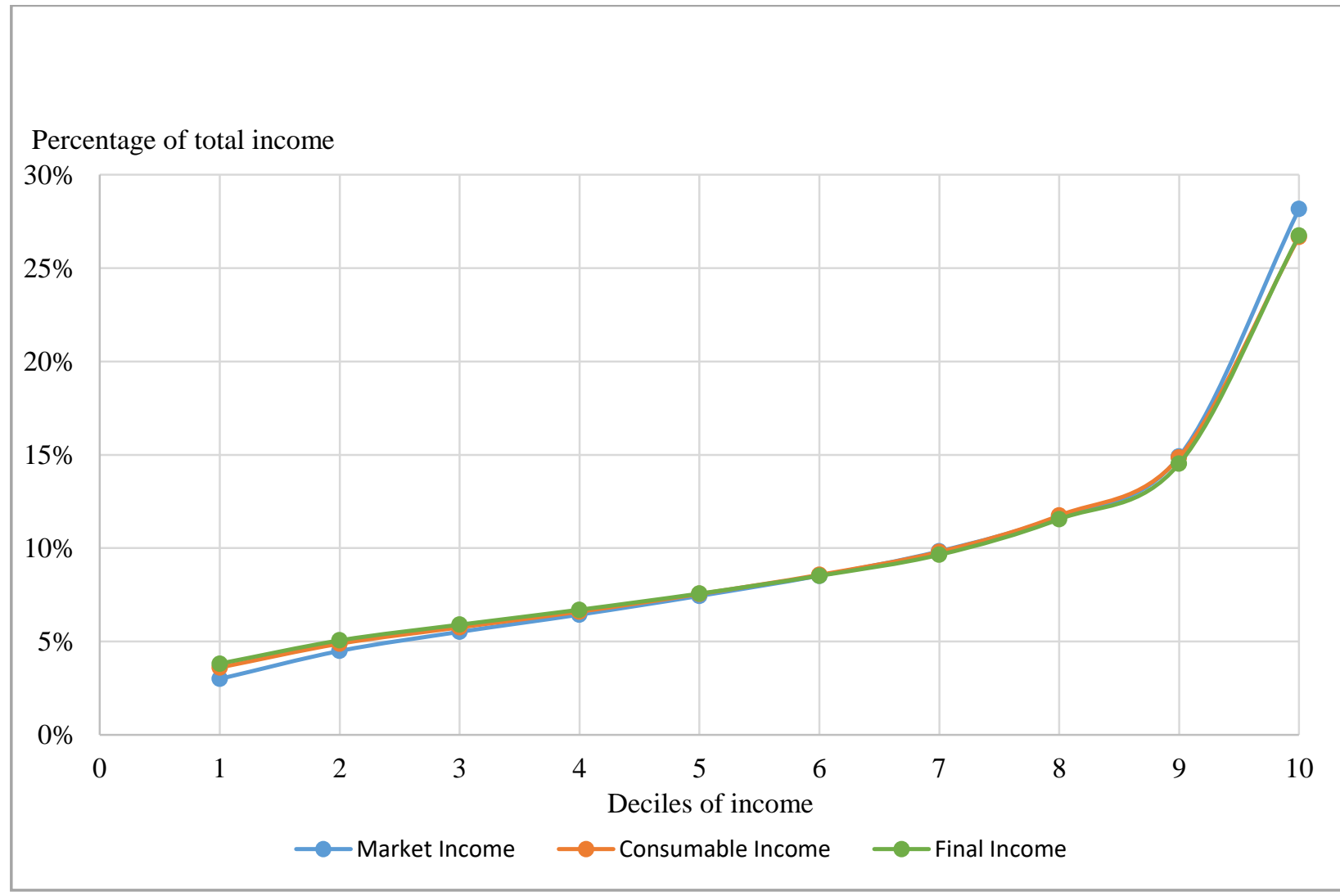

Source: 2010 Household Expenditure and Income Survey (HEIS) data and Jordan Department of Statistics national accounts database, http://web.dos.gov.jo/sectors/national-account/?lang=en.

Note: "Market income" comprises pretax wages, salaries, income earned from capital assets (rent, interest, or dividends), and private transfers. "Consumable income" is constructed by (a) subtracting from market income the payments for personal income taxes, social security contributions, and sales taxes; and (b) adding direct cash transfers. "Final income" adds to consumable income the benefits of in-kind transfers for education and health care.

A deficiency in such an analysis by income decile is that it does not tell us the within-decile impacts. Nor does it tell us the specific impact of the fiscal policy on the poor, as defined by a poverty line. To better understand this impact on the poor, we divide Jordan's population into six income groups for analysis under two income concepts: market income and consumable income.

Based on per capita income per day (in 2005 purchasing power parity [PPP] prices) the six income groups are as follows: less than US $\$ 1.25$; US $\$ 1.25-U S \$ 2.50$; US $\$ 2.50-U S \$ 4$; US $\$ 4$ US $\$ 10$; US $\$ 10-U S \$ 50$; and more than US $\$ 50$. Figure 2 presents the fraction of Jordan's population within each income group by income concept. 
The result clearly demonstrates that fewer people are below the poverty lines of US $\$ 2.50$ and US $\$ 4$ a day according to their consumable income than they are according to their market income. Instead, a significantly greater percentage of people are in the middle income range (of US $\$ 4-U S \$ 10$ and US\$10-US\$50) according to their consumable income than according to their market income. This result strongly suggests that people who were below the poverty line according to their market income rise above the poverty line in their consumable income through government's fiscal interventions.

\section{Figure 2 Share of Population in Different Income Groups in Jordan, by Income Concept, 2010}

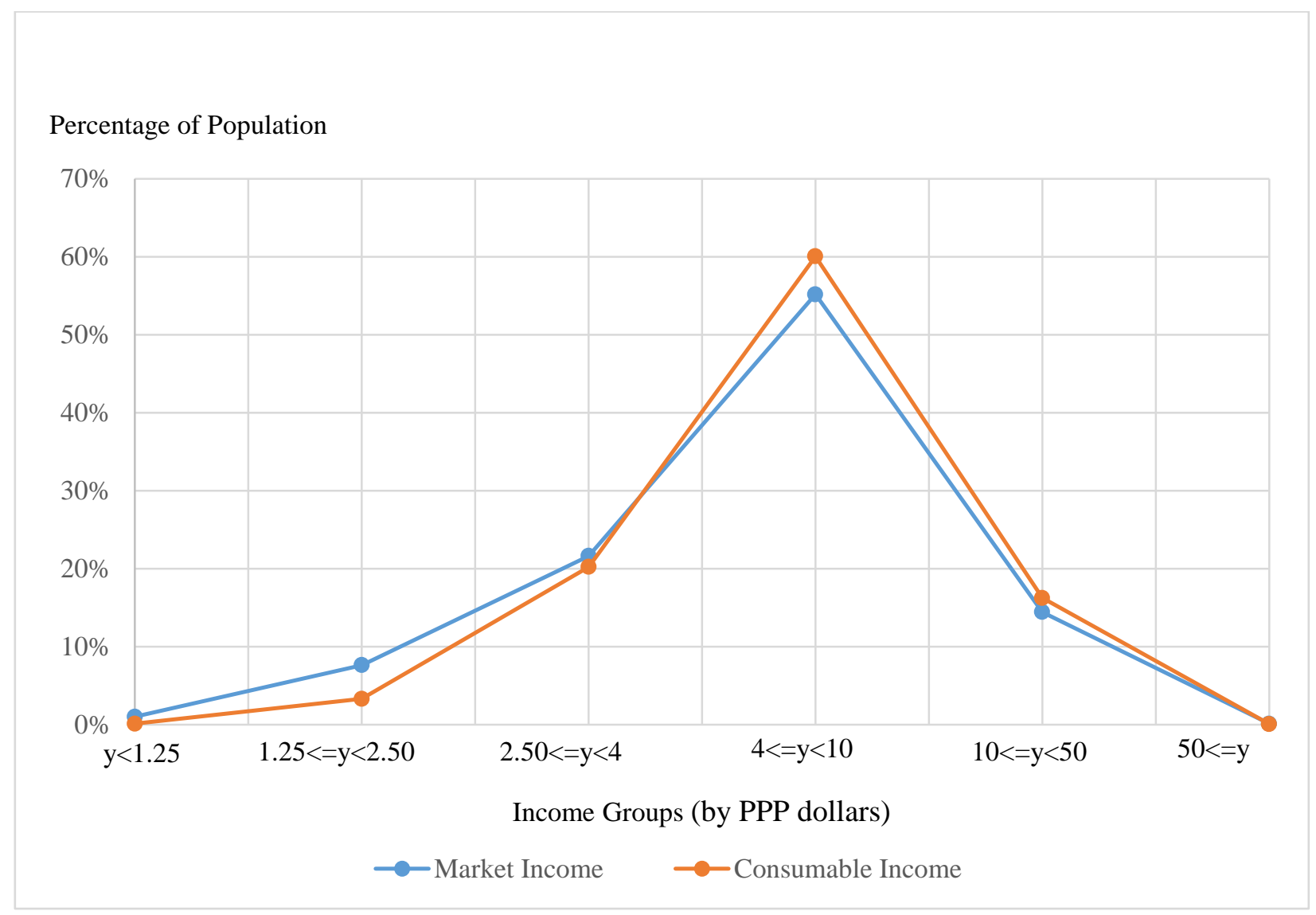

Source: 2010 Household Expenditure and Income Survey (HEIS) data" and "Jordan Department of Statistics national accounts database, http://web.dos.gov.jo/sectors/national-account/?lang=en.

Note: Income groups are defined by income per capita per day in U.S. dollars in 2005 purchasing power parity (PPP) terms. "Market income" comprises pretax wages, salaries, income earned from capital assets (rent, interest, or dividends), and private transfers. "Consumable income" is constructed by (a) subtracting from market income the payments for personal income taxes, social security contributions, and sales taxes; and (b) adding direct cash transfers. 


\section{Poverty and Inequality Incidence}

Next, we analyze the incidence results related to poverty and inequality. The results are presented in table 3. The poverty headcount indexes suggest that the Jordanian government's fiscal interventions have been quite successful in reducing poverty. At the level of US\$4 a day (2005 PPP), the percentage of people below the poverty line decreases by 6.7 percentage points when we move from market income to consumable income. Similarly, at Jordan's official national poverty line, the poverty headcount decreases by 6.8 percentage points when we move from market income to consumable income. ${ }^{13}$

When we examine the overall impact of Jordan's fiscal policy on inequality, we find that the Gini coefficient decreases from 0.35 to 0.32 when we move from the initial market income to the final income (table 3). This indicates that, overall, Jordan's fiscal policies reduced inequality in the country. Additionally, the Gini coefficient decreases as we move from each income concept to the next, showing that each set of fiscal interventions being measured decreases inequality.

Table 3 Poverty and Inequality Incidence in Jordan, by Income Concept, 2010

\begin{tabular}{|c|c|c|c|c|c|}
\hline Indicator & $\begin{array}{l}\text { Market } \\
\text { income }^{\text {a }}\end{array}$ & $\begin{array}{c}\text { Market } \\
\text { income }+ \\
\text { contributory } \\
\text { pensions }\end{array}$ & $\begin{array}{l}\text { Disposable } \\
\text { income }^{b}\end{array}$ & $\begin{array}{l}\text { Consumable } \\
\text { income }^{c}\end{array}$ & $\begin{array}{c}\text { Final } \\
\text { income }^{d}\end{array}$ \\
\hline Gini & 0.350 & 0.342 & 0.328 & 0.325 & 0.319 \\
\hline \multicolumn{6}{|l|}{ US\$1.25 per day PPP } \\
\hline Headcount index $(\%)$ & 1.0 & 0.5 & 0.1 & 0.1 & n.a. \\
\hline Poverty gap (\%) & 0.3 & 0.2 & 0.0 & 0.0 & n.a. \\
\hline $\begin{array}{l}\text { Fiscal impoverishment } \\
\text { headcount }(\%)\end{array}$ & n.a. & n.a. & 0 & 0 & 0 \\
\hline \multicolumn{6}{|l|}{ US\$2.50 per day PPP } \\
\hline Headcount index $(\%)$ & 8.6 & 5.2 & 4.0 & 3.4 & n.a. \\
\hline Poverty gap (\%) & 2.0 & 1.1 & 0.7 & 0.6 & n.a. \\
\hline $\begin{array}{l}\text { Fiscal impoverishment } \\
\text { headcount }(\%)\end{array}$ & n.a. & n.a. & 0.0 & 2.6 & 1.6 \\
\hline
\end{tabular}

\footnotetext{
13 The national poverty line in Jordan is determined from the "cost of basic needs," based on a national caloric requirement of 2,347 calories per capita per day and a common food and nonfood basket for all households. The poverty line is based on the consumption and expenditure patterns of the bottom 30 percent of the population (poor or near-poor) as reflected in the 2010 HEIS (Jolliffe and Serajuddin 2015). The estimated poverty line to meet basic needs was set at JD 813.7 per person per day in 2010 (US\$3.42 per day 2005 PPP).
} 
US\$4 PPP

\begin{tabular}{|c|c|c|c|c|c|}
\hline Headcount index $(\%)$ & 30.3 & 25.8 & 24.6 & 23.6 & n.a. \\
\hline Poverty gap (\%) & 8.3 & 6.2 & 5.4 & 5.1 & n.a. \\
\hline $\begin{array}{l}\text { Fiscal impoverishment } \\
\text { headcount }(\%)\end{array}$ & n.a. & n.a. & 0.5 & 13.2 & 3.1 \\
\hline \multicolumn{6}{|l|}{ National poverty line } \\
\hline Headcount index $(\%)$ & 20.5 & 15.8 & 14.3 & 13.7 & n.a. \\
\hline Poverty gap (\%) & 5.1 & 3.5 & 2.8 & 2.5 & n.a. \\
\hline
\end{tabular}

Source: Based on 2010 Household Expenditure and Income Survey (HEIS) data.

Note: PPP = purchasing power parity. n.a. = not applicable. The Gini coefficient measures the relative inequality of income distribution, ranging from 0 (full equality) to 1 (maximum inequality). The "poverty headcount" is the percentage of the population living in poverty below a specified poverty line. The "poverty gap" is the average percentage by which poor individuals fall below a given poverty line. The "fiscal impoverishment headcount" measures the percentage of the poor adversely affected (that is, whose incomes decrease) as a result of fiscal policies (Higgins and Lustig 2016). It is based on the percentages of postfiscal poor (that is, according to disposable, consumable, and final income).

a. Market income comprises pretax wages, salaries, income earned from capital assets (rent, interest, or dividends), and private transfers.

b. Disposable income (a) subtracts from market income the payments for personal income taxes and social security contributions, and (b) adds direct cash transfers.

c. Consumable income adds to disposable income the impact of sales taxes.

d. Final income adds to consumable income the effects of in-kind transfers for health care and education

e. The national poverty line in Jordan is determined from the "cost of basic needs," based on the consumption and expenditure patterns of the bottom 30 percent of the population (poor or near-poor) in the 2010 HEIS data (Jolliffe and Serajuddin 2015). The estimated poverty line to meet basic needs was set at JD 813.7 per person per day in 2010 (US\$3.42 per day at 2005 PPP).

This reduction in poverty numbers across income groups is also reflected in Figure 3, which shows the percentage of cumulative income in Jordan earned by the poorest income groups across the different income concepts. 
Figure 3 Percentage of Cumulative Income Earned by the Poor in Jordan, by Income Concept, 2010

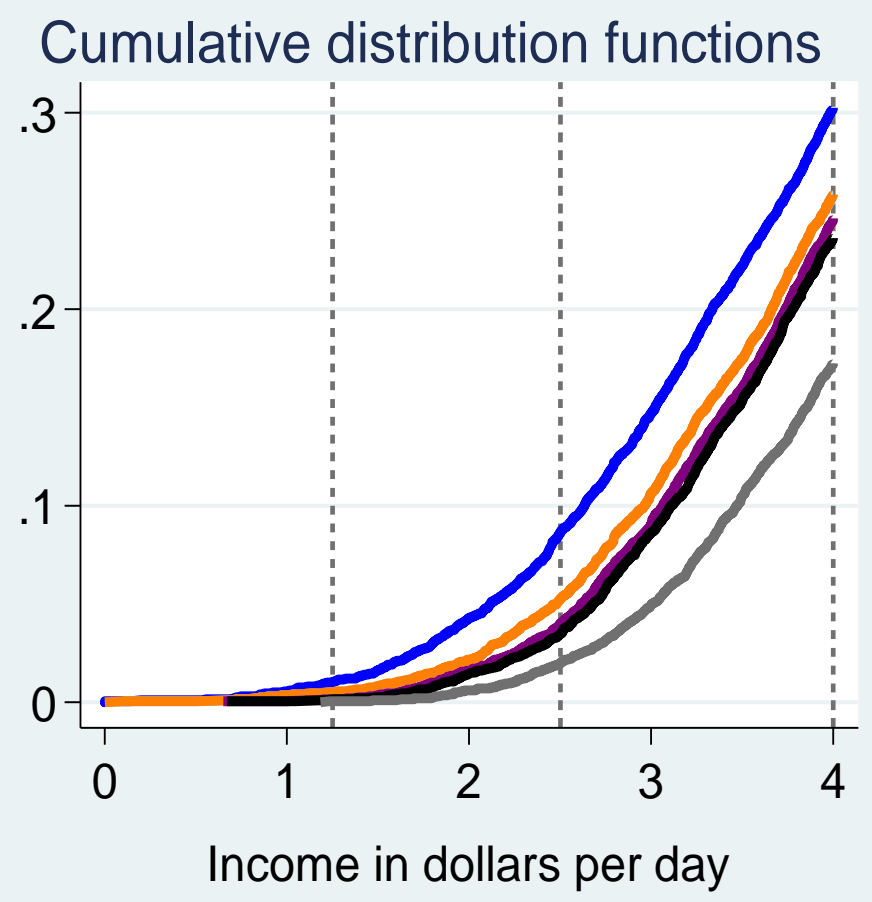

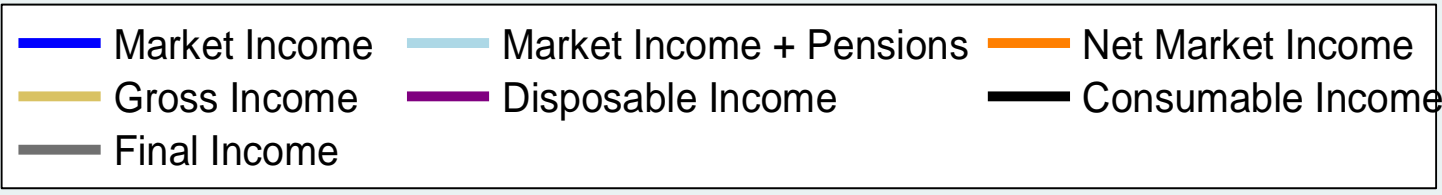

Source: 2010 Household Expenditure and Income Survey (HEIS) data" and "Jordan Department of Statistics national accounts database http://web.dos.gov.jo/sectors/national-account/?lang=en.

Note: Vertical dotted lines designate three poverty lines (in 2005 PPP terms): US $\$ 1.25$, US $\$ 2.50$, and US $\$ 4$. "Market income" comprises pretax wages, salaries, income earned from capital assets (rent, interest, or dividends), and private transfers. "Net market income" subtracts direct (income) taxes from market income. "Disposable income" is constructed by adding direct cash transfers to net market income. "Consumable income" subtracts from disposable income the impact of sales taxes paid. "Final income" adds to consumable income the effects of in-kind transfers for health care and education.

To understand the fairness of these fiscal interventions, we next employ a measure called "fiscal impoverishment," as proposed by Higgins and Lustig (2016). This measure allows us to examine the proportion of the poor adversely affected (that is, whose incomes decrease) by fiscal policies.

At both the US $\$ 2.50$-a-day and US $\$ 4$-a-day poverty lines (2005 PPP), fiscal impoverishment increases significantly (by 2.6 points and 12.7 points, respectively) when we move from disposable income to consumable income, as shown in table 3 . This suggests that indirect taxes 
may be making some of the poor even poorer. However, it is important to note that indirect taxes would have different effects on different individuals depending on their spending patterns. We do not see such large fiscal impoverishment for movements between any of the other income concepts. We will further detail the impact of each of these interventions later in this working paper.

\section{Progressivity of Fiscal Interventions}

Our next task is to determine whether the fiscal system in Jordan is progressive or regressive. To illustrate whether policies are having a progressive or regressive impact, we show the cumulative proportion of taxes and transfers for the population by income percentile in figure 6.4 .

The figure clearly shows that direct taxes and direct transfers are very progressive, while the indirect taxes appear to be slightly regressive. The curve for direct taxes shows a high concentration at the highest end of the income distribution, and the curve for direct transfers shows the highest concentration at the lowest end of the distribution.

Figure 6.4 Progressivity of Taxes and Transfers in Jordan, 2010

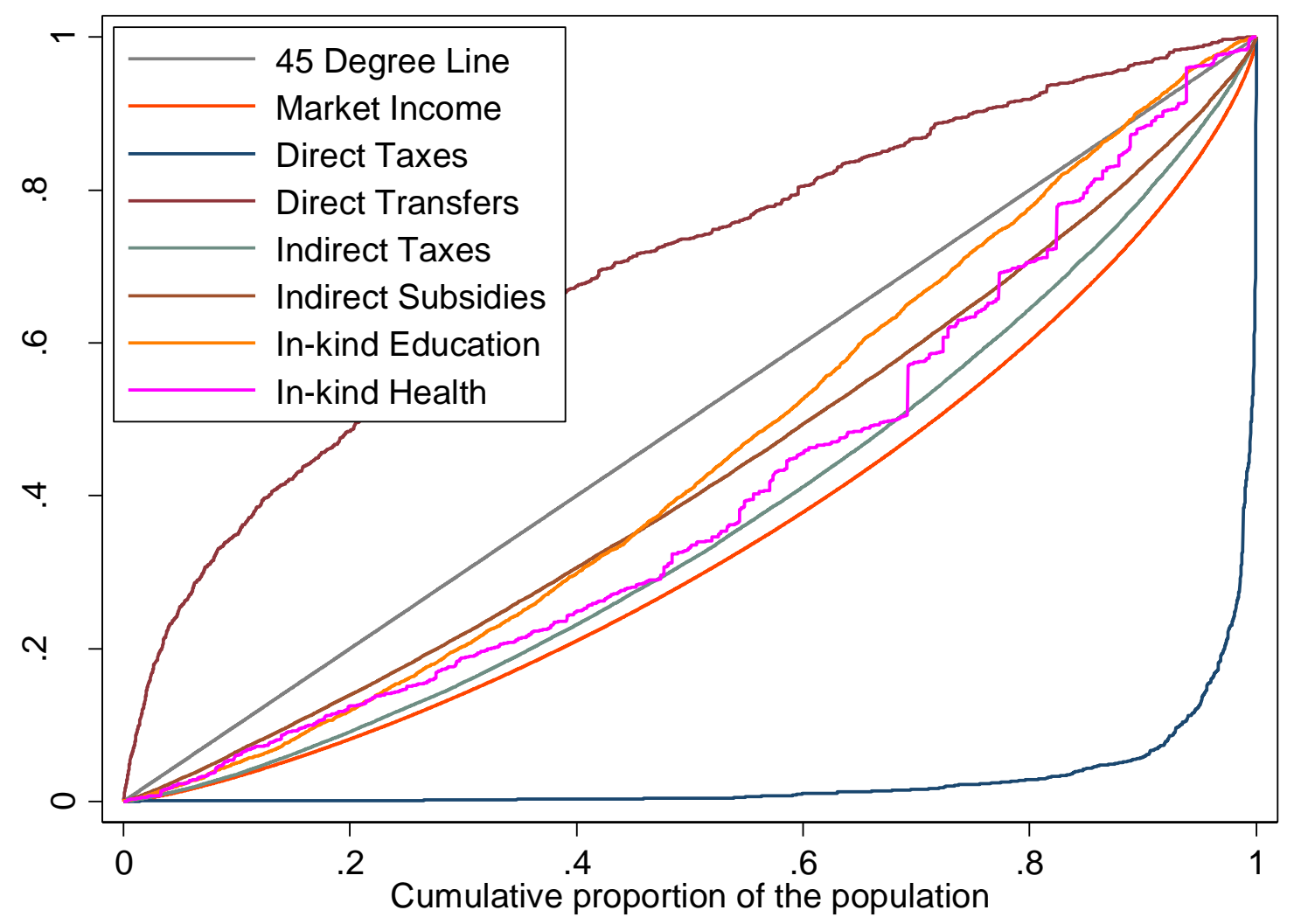

Source: Based on 2010 Household Expenditure and Income Survey (HEIS) data. 
Note: Figure shows concentration curves for taxes and transfers, and a Lorenz curve representing the distribution of "market income," which comprises pretax wages, salaries, and income earned from capital assets (rent, interest, or dividends) and private transfers. "Direct taxes" include income, capital gains, and property taxes. "Indirect taxes" include general sales taxes.

a. The cumulative share of the population is ordered by market income.

Furthermore, the Kakwani coefficients suggest that direct taxes, direct transfers, indirect subsidies, and in-kind education are strongly progressive (table 4). In-kind health benefits have close to a proportional effect on income. However, as suggested by the Gini index results, indirect taxes (GST) have a slightly regressive effect. ${ }^{14}$

To get a more methodical understanding of the progressivity of each of these fiscal interventions, we rely on the marginal contributions of these interventions to the changes in the Gini coefficient. ${ }^{15}$ In Jordan, direct taxes and direct transfers are equalizing (table 4). Indirect subsidies are equalizing, too, but indirect taxes are nonequalizing. Education spending is quite equalizing, but health spending is slightly nonequalizing. The equalizing effect of education dominates; hence, in-kind spending overall is equalizing.

${ }^{14}$ See Inchauste and Lustig (2017) for detailed discussions of how Kakwani coefficients, marginal contributions, and other methodologies are used in the assessments of the progressivity, regressivity, and pro-poorness of the fiscal interventions examined in this volume.

${ }^{15}$ For a discussion of the properties of the marginal contribution, see Enami, Lustig, and Aranda (2018). 
Table 4 Kakwani Coefficients for, and Marginal Contributions to Redistribution of, Taxes and Social Spending in Jordan, 2010

\section{Marginal contribution, by income concept ${ }^{b}$ (change in Gini index)}

\begin{tabular}{lcccc}
\cline { 3 - 4 } \multicolumn{1}{c}{ Fiscal intervention } & $\begin{array}{c}\text { Kakwani } \\
\text { coefficient }\end{array}$ & $\begin{array}{c}\text { Market to } \\
\text { disposable } \\
\text { income }\end{array}$ & $\begin{array}{c}\text { Market to } \\
\text { consumable } \\
\text { income }\end{array}$ & $\begin{array}{c}\text { Market to } \\
\text { final income }\end{array}$ \\
\cline { 2 - 4 } All direct taxes and contributions & 0.203 & 0.007 & 0.007 & 0.006 \\
Direct taxes & 0.594 & 0.008 & 0.008 & n.a. \\
Direct transfers & 0.550 & 0.006 & 0.005 & 0.005 \\
Indirect taxes: GST & -0.066 & n.a. & -0.002 & -0.001 \\
Indirect subsidies & 0.151 & n.a. & 0.005 & 0.004 \\
All taxes & 0.126 & n.a. & 0.006 & n.a. \\
In-kind health & 0.056 & n.a. & n.a. & -0.009 \\
In-kind education & 0.478 & n.a. & n.a. & 0.015 \\
$\quad$ Kindergarten & 0.666 & n.a. & n.a. & 0.000 \\
$\quad$ Primary & 0.581 & n.a. & n.a. & 0.013 \\
Secondary & 0.403 & n.a. & n.a. & 0.002 \\
Tertiary & 0.006 & n.a. & n.a. & 0.000 \\
All in-kind & 0.344 & n.a. & n.a. & 0.025 \\
\hline
\end{tabular}

Source: Based on 2010 Household Expenditure and Income Survey (HEIS) data.

Note: n.a. $=$ not applicable. GST $=$ general sales tax. The Gini coefficient measures the relative inequality of income distribution, ranging from 0 (full equality) to 1 (maximum inequality).

a. Kakwani coefficients measure whether a fiscal intervention exercises an equalizing or unequalizing force; progressive interventions have positive Kakwani coefficients, and regressive ones have negative coefficients.

b. The "marginal contribution" is the difference between the Gini coefficients with and without the designated row's tax or expenditure. Income concepts are as follows: "Market income" comprises pretax wages, salaries, and income earned from capital assets (rent, interest, or dividends) and private transfers. "Disposable income" is constructed by adding direct cash transfers to net market income. "Consumable income" adds to disposable income the impact of indirect taxes, including value-added taxes; import duties; and excises on petroleum products, alcoholic beverages, and tobacco products. "Final income" adds (to consumable income) the value of in-kind transfers including health care and education.

It is also important to understand whether the redistributive effect that we have seen in the figures and tables result from vertical equity (VE) between the rich and poor households rather 
than from simple reranking (RR) of households. VE tells us the amount of inequality reduction that would be possible if the tax and transfer system treated equals (that is, two households with same level of income) equally (Duclos 2008). In contrast, RR is a measure of inequity, which shows whether a poorer household becomes wealthier than a comparatively richer household after a government transfer or tax intervention (Duclos, Jalbert, and Araar 2003).

The redistributive effect in Jordan is mostly occurring through VE (table 5). We find that RR represents somewhere between 2 percent and 34 percent of the magnitude of VE, depending on the income concept, which shows that horizontal inequity in the form of RR is relatively low. This suggests that most of the redistributive effect from fiscal interventions occurred through VE. ${ }^{16}$

Table 5 Redistributive, Vertical Equity, and Reranking Effects of Fiscal Policy in Jordan, 2010

\begin{tabular}{|c|c|c|c|c|}
\hline Indicator & $\begin{array}{l}\text { Market income } \\
\text { to net market } \\
\text { income }^{\mathrm{b}}\end{array}$ & $\begin{array}{c}\text { Market income } \\
\text { to disposable } \\
\text { income }^{\mathrm{c}}\end{array}$ & $\begin{array}{c}\text { Market income } \\
\text { to consumable } \\
\text { incomed }^{\mathrm{d}}\end{array}$ & $\begin{array}{c}\text { Market } \\
\text { income to } \\
\text { final income }\end{array}$ \\
\hline $\begin{array}{l}\text { Redistributive effect } \\
\text { (change in Gini) }^{\mathrm{f}}\end{array}$ & 0.0076 & 0.0132 & 0.0161 & 0.0230 \\
\hline $\begin{array}{l}\text { Vertical equity (VE) } \\
\text { (change in Gini)g }\end{array}$ & 0.0077 & 0.0149 & 0.0180 & 0.0348 \\
\hline $\begin{array}{l}\text { Reranking (RR) } \\
\text { (change in Gini) }^{\mathrm{h}}\end{array}$ & 0.0001 & 0.0017 & 0.0019 & 0.0118 \\
\hline $\begin{array}{l}\text { Horizontal inequity } \\
(\mathrm{RR} \text { as } \% \text { of } \mathrm{VE})\end{array}$ & 2 & 11 & 11 & 34 \\
\hline \multicolumn{5}{|c|}{ Source: Based on 2010 Household Expenditure and Income Survey (HEIS) data. } \\
\hline \multicolumn{5}{|c|}{$\begin{array}{l}\text { Note: The Gini coefficient measures the inequality of income distribution, ranging from } 0 \text { (full equality) to } 1 \\
\text { (maximum inequality). }\end{array}$} \\
\hline \multicolumn{5}{|c|}{$\begin{array}{l}\text { a. Market income comprises pretax wages, salaries, income earned from capital assets (rent, interest, or dividends), } \\
\text { and private transfers. }\end{array}$} \\
\hline \multicolumn{5}{|c|}{ b. Net market income is market income minus direct taxes. } \\
\hline \multicolumn{5}{|c|}{ c. Disposable income is constructed by adding direct cash transfers to net market income. } \\
\hline \multicolumn{5}{|c|}{$\begin{array}{l}\text { d. Consumable income adds to disposable income the impact of indirect taxes, including value-added taxes; } \\
\text { import duties; and excises on petroleum products, alcoholic beverages, and tobacco products. }\end{array}$} \\
\hline
\end{tabular}

\footnotetext{
${ }^{16}$ For more about how vertical equity, reranking, and horizontal inequity are defined and used in the analyses throughout this volume, see Inchauste and Lustig (2017).
} 
f. The "redistributive effect" refers to the change in inequality associated with direct and indirect taxes as well as direct transfers and subsidies, calculated in terms of the change in Gini coefficient.

g. "Vertical equity" (VE) tells us the amount of inequality reduction that would be possible if the tax and transfer system treated equals equally.

h. The "reranking" (RR) effect is a measure of inequity, which shows whether a poorer household becomes wealthier than a comparatively richer household after a government transfer or tax intervention,

\section{Income Mobility}

Finally, it is important to examine the income mobility of the poor. Figure 2 earlier provided evidence of upward income mobility in the transition from market income to final income. To further understand the details of the transition, we have created a mobility matrix that shows the fractions of individuals in certain income groups who transition to other income groups (table 6). This will help us calculate the percentage of people living beneath a certain poverty line who transition out of poverty. To conduct this analysis, we have created two mobility matrixes, showing the transition from market income (including pension) to (a) disposable income, and (b) consumable income.

Table 6 Mobility of Jordanian Households across Income Concepts, by Income Group, 2010

percentage

\section{Disposable income group (y)}

\begin{tabular}{lccccccc}
$\begin{array}{c}\text { Market income } \\
+ \text { pensions } \\
\text { group }(\mathrm{y})\end{array}$ & $\mathrm{y}<1.25$ & $\begin{array}{c}1.25 \leq \mathrm{y} \\
<2.50\end{array}$ & $\begin{array}{c}2.50 \leq \mathrm{y} \\
<4.00\end{array}$ & $\begin{array}{c}4.00 \leq \mathrm{y} \\
<10.00\end{array}$ & $\begin{array}{c}10.00 \leq \mathrm{y} \\
<50.00\end{array}$ & $50.00 \leq \mathrm{y}$ & $\begin{array}{c}\text { Share of } \\
\text { population } \\
(\%)\end{array}$ \\
\hline $\mathrm{y}<1.25$ & 13 & 58 & 18 & 11 & 0 & 0 & 0.9 \\
$1.25 \leq \mathrm{y}<2.50$ & 0 & 65 & 30 & 6 & 0 & 0 & 5.5 \\
$2.50 \leq \mathrm{y}<4.00$ & 0 & 0 & 92 & 8 & 0 & 0 & 20.9 \\
$4.00 \leq \mathrm{y}<10.00$ & 0 & 0 & 0 & 99 & 1 & 0 & 57.0 \\
$10.00 \leq \mathrm{y}<50.00$ & 0 & 0 & 0 & 1 & 99 & 0 & 15.6 \\
$50.00 \leq \mathrm{y}$ & 0 & 0 & 0 & 0 & 62 & 38 & 0.1 \\
\hline
\end{tabular}




\section{Consumable income group (y)}

\begin{tabular}{lccccccc}
$\begin{array}{c}\text { Market income } \\
+ \text { pensions } \\
\text { group }(\mathrm{y})\end{array}$ & $\mathrm{y}<1.25$ & $\begin{array}{c}1.25 \leq \mathrm{y} \\
<2.50\end{array}$ & $\begin{array}{c}2.50 \leq \mathrm{y} \\
<4.00\end{array}$ & $\begin{array}{c}4.00 \leq \mathrm{y} \\
<10.00\end{array}$ & $\begin{array}{c}10.00 \leq \mathrm{y} \\
<50.00\end{array}$ & $50.00 \leq \mathrm{y}$ & $\begin{array}{c}\text { Share of } \\
\text { population } \\
(\%)\end{array}$ \\
\hline $\mathrm{y}<1.25$ & 9 & 54 & 25 & 11 & 0 & 0 & 0.9 \\
$1.25 \leq \mathrm{y}<2.50$ & 0 & 46 & 47 & 8 & 0 & 0 & 5.5 \\
$2.50 \leq \mathrm{y}<4.00$ & 0 & 0 & 81 & 19 & 0 & 0 & 20.9 \\
$4.00 \leq \mathrm{y}<10.00$ & 0 & 0 & 0 & 98 & 2 & 0 & 57.0 \\
$10.00 \leq \mathrm{y}<50.00$ & 0 & 0 & 0 & 1 & 99 & 0 & 15.6 \\
$50.00 \leq \mathrm{y}$ & 0 & 0 & 0 & 0 & 53 & 47 & 0.1 \\
\hline
\end{tabular}

Source: Based on 2010 Household Expenditure and Income Survey (HEIS) data.

Note: All income groups stated in terms of U.S. dollars per person per day (in 2005 PPP terms). Shaded cells designate same income group across two income concepts.

a. Market income comprises pretax wages, salaries, income earned from capital assets (rent, interest, or dividends), and private transfers.

b. Disposable income is constructed by adding direct cash transfers to net market income.

c. Consumable income adds to disposable income the impact of indirect taxes, including value-added taxes; import duties; and excises on petroleum products, alcoholic beverages, and tobacco products.

The results show that the fiscal interventions had contributed toward a clear upward mobility for the people below various poverty lines across income concepts, for example, as follows:

- Of those with market incomes of US\$1.25-US\$2.50 PPP per day, 30 percent moved to a higher income bracket of US\$2.50-US\$4.00 PPP per day for their disposable income, and 47 percent moved to the higher bracket for their consumable income. Interestingly, a small percentage of households moved to an even higher income bracket of US\$4-US\$10 PPP per day. Six percent moved to this higher bracket for their disposable income, and 8 percent moved to the higher bracket for their consumable income.

- Of those with market incomes of US\$2.50-US\$4.00 a day (that is, under the poverty line of US\$4 PPP a day), 8 percent improved to US\$4-US\$10 a day for their disposable income, and 19 percent for their consumable income.

In addition to these improvements, it is also important to note that none of the households with market income below the poverty line suffered from any deteriorations that forced their disposable, consumable, or final income to deteriorate into a lower income group. Overall, these results suggest that the poor benefited strongly from the Jordanian government's fiscal policies. 


\section{Conclusion}

This working paper has analyzed the impact of Jordanian government's fiscal policies on poverty and inequality in the country. We use data from Jordan's 2010 HEIS and records from administrative accounts, applying the CEQ methodology in our analysis. We cover all the key fiscal policies employed by the government, such as direct taxes (personal income taxes); indirect taxes (sales taxes); direct transfers; indirect subsidies (subsidies for food, oil, electricity, and water); and in-kind benefits (benefits for education and health).

Our results indicate that the Jordan's policies are mostly progressive and equalizing, primarily through direct taxes, direct transfers, indirect subsidies, and in-kind benefits. Moreover, the results show that the combination of tax and expenditure policies is poverty-reducing. However, the indirect tax system, in its current form, is slightly regressive and inequalityincreasing, as the poor are paying a greater fraction of their income than the rich as sales tax. 


\section{References}

Al Jabery, M., and M. Zumberg. 2008. "General and Special Education Systems in Jordan: Present and Future Perspectives." International Journal of Special Education 23 (1): 115-22.

Atamanov, A., J. Jellema, and U. Serajuddin. 2015. "Energy Subsidy Reform in Jordan: Welfare Implications of Different Scenarios.” Policy Research Working Paper 7313. World Bank, Washington, DC.

Atkinson, A., and A. Brandolini. 2001. "Promise and Pitfalls in the Use of 'Secondary' DataSets: Income Inequality in OECD Countries as a Case Study." Journal of Economic Literature 39 (3): 771-99.

Deaton, A. 1997. The Analysis of Household Surveys: A Microeconometric Approach to Development Policy. Washington, DC: World Bank.

DOS (Department of Statistics, Jordan), Statistical Yearbook 2012, Annual statistical report, (Amman, 2012), http://www.dos.gov.jo/dos home a/main/yearbook 2012.pdf.

DOS (Department of Statistics, Jordan) and World Bank, Hashemite Kingdom of Jordan: Poverty Update_Volume 1: Main Report, Report No. 47951-JO, World Bank, (Washington, DC, 2009).

Duclos, Jean-Yves. 2008. "Horizontal and Vertical Equity." In The New Palgrave Dictionary of Economics, 2d ed., edited by Steven N. Durlauf and Lawrence E. Blume. Basingstoke, U.K.: Palgrave Macmillan.

Duclos, Jean-Yves, Vincent Jalbert, and Abdelkrim Araar. 2003. "Classical Horizontal Inequity and Reranking: An Integrating Approach." In Fiscal Policy, Inequality, and Welfare (Research on Economic Inequality Series, Book 10), edited by Yoram Amiel and John A. Bishop, 65-100. Bingley, U.K.: Emerald Group Publishing Ltd.

Enami, Ali, Nora Lustig, and Rodrigo Aranda. 2018. "Analytical Foundations: Measuring the Redistributive Impact of Taxes and Transfers." Chapter 2 in Commitment to Equity Handbook. Estimating the Impact of Fiscal Policy on Inequality and Poverty, edited by Nora Lustig (Brookings Institution Press and CEQ Institute, Tulane University). Advance online version available at http://www.commitmentoequity.org/publications/handbook.php.

Government of Jordan, Jordan 2025: A National Vision and Strategy, Economic blueprint document, Hashemite Kingdom of Jordan, (Amman, 2015). 
Heredia-Ortiz, E. 2013. "Evaluating Tax Expenditures in Jordan: Jordan Fiscal Reform II Project." Publication prepared for the Jordan Economic Growth Office of the U.S. Agency for International Development (USAID), Amman.

Higgins, Sean, and Nora Lustig. 2016. "Can a Poverty-Reducing and Progressive Tax and Transfer System Hurt the Poor?" Journal of Development Economics 122 (September 2016): $63-75$.

IMF (International Monetary Fund). 2012. "Jordan: 2012 Article IV Consultation-Staff Report and Public Information Notice." Country Report No. 12/119, IMF, Washington, DC.

Inchauste, Gabriela and Nora Lustig. 2017. "Overview: Fiscal Policy and Redistribution." In Distributional Impact of Fiscal Policy: Evidence from Developing Countries, edited by Gabriela Inchauste and Nora Lustig. Washington D.C.: World Bank.

Inchauste, Gabriela, Y. Mansur, and U. Serajuddin. 2017. "Jordan: Reform amid Turmoil.” In The Political Economy of Subsidy Reform, edited by G. Inchauste and D. G. Victor, 209-42. Directions in Development Series. Washington, DC: World Bank.

Jolliffe, Dean Mitchell, and Umar Serajuddin. 2015. "Estimating Poverty with Panel Data, Comparably: An Example from Jordan.” Policy Research Working Paper 7373. World Bank, Washington, DC.

Lustig, Nora, and Sean Higgins. 2013. "Commitment to Equity Assessment (CEQ): Estimating the Incidence of Social Spending, Subsidies and Taxes." Handbook and Commitment to Equity (CEQ) Working Paper No. 1. Center for Inter-American Policy and Research (CIPR); the Inter-American Dialogue; and Department of Economics, Tulane University, New Orleans.

Mansour, Wael. 2012. "The Patterns and Determinants of Household Welfare Growth in Jordan 2002-2010.” Policy Research Working Paper 6249. World Bank, Washington, DC.

MoH (Ministry of Health, Jordan), Ministry of Health Annual Statistical Book 2012, Annual report, $\mathrm{MoH}$, Hashemite Kingdom of Jordan, (Amman, 2012).

MoF (Ministry of Finance, Jordan), Jordan General Government Finance Bulletin - July 2013, Monthly report, Studies and Economic Policies Directorate, MoF, Hashemite Kingdom of Jordan, (Amman, 2013).

Ravallion, M. 2003. "The Debate on Globalization, Poverty and Inequality: Why Measurement Matters.” International Affairs 79 (4): 739-53. 
Silva, J., V. Levin, and M. Morgandi. 2013. Inclusion and Resilience: The Way Forward for Social Safety Nets in the Middle East and North Africa. Washington, DC: World Bank.

Thomas, D., J. Strauss, and M. Henriques. 1991. "How Does Mother's Education Affect Child Height?" The Journal of Human Resources 26 (2): 183-211.

WHO (World Health Organization). 2006. "Health System Profile-Jordan.” Country health system report, Regional Health Systems Observatory, Regional Office for the Eastern Mediterranean (EMRO), WHO, Cairo.

World Bank. 2012a. "The Hashemite Kingdom of Jordan: A Note on Updating Poverty Measurement Methodology." Background paper for the Jordan Poverty Reduction Strategy. World Bank, Washington, DC.

World Bank. 2012b. "Hashemite Kingdom of Jordan: Options for Immediate Fiscal Adjustment and Longer Term Consolidation.” Report No. 71979-JO, World Bank, Washington, DC. 